\title{
Genes and populations in susceptibility to celiac disease
}

It was in 1996 that Zhong (1) published the first pangenomic association study related to celiac disease (CD). Since then, as Professor Ludwig Sollid was to write in an editorial in 2008 (2), gene hunting season remained open as regards to CD. The association between this condition and MHC genes was well known but it was only a few years earlier that at-risk HLA-DQB1 and DQA1 alleles had been specifically defined (3). However, while HLA is a key region for CD susceptibility, it only represents around $40 \%$ of the genetic budget. Almost ten years after the paper by Zhong, Monsuur et al. found an association between $\mathrm{CD}$ and gene variants for an unconventional myosin, MYO9B (4), in a hot spot on chromosome 19 (19p13.1) that had been previously defined by the same team (5). This is not merely another finding in the race towards understanding susceptibility genes in this disease; in addition to being an early fruit of modern genomic platforms in the study of complex genetic disorders, it reveals the contribution of genes not directly associated with the immune system to the pathogenesis of $\mathrm{CD}$, as it relates this condition to a gene potentially involved in epithelial permeability.

The aforementioned study was initially performed on a Dutch population (4), and was not validated for other European populations -including the Italian and Spanish ones- later studied (6-10). These same results, with variable findings depending on study population, have been replicated for other susceptibility genes defined in subsequent association studies (GWAS, Genome Wide Association Studies) (11-13), using technologies allowing to analyze numbers of samples from both patients and controls that were unconceivable during last century's closing decade.

While the association of gene $M Y O 9 B$ with $C D$ was never validated in the various European populations, it did reveal the association of this gene with other immune illnesses, including type-1 diabetes mellitus, rheumatoid arthritis and ulcerative colitis, where mucosal permeability changes may account for loss of tolerance for a number of (auto)antigens. Therefore, the results obtained by Loeff et al. (14) should be unsurprising. In previous studies Pérez-Bravo et al. had revealed that the distribution of HLA class II haplotypes in the Chilean population differs from that seen among people with European ascentry, with a higher predominance of DQ8-carrying haplotypes in the indigenous inhabitants $(15,16)$. However, both CD presentation and frequency are similar to those seen in the European population. It would be interesting to know whether susceptibility alleles come from the European or Amerindian population layer; or if no relation exists to ethnical origin, these may act as facilitators in the development of the pathogenic mechanism once the population contacts environmental gluten.

There is currently a list of over 30 CD-related genes, some of which also play a role in other gastrointestinal or immune-related diseases, and in highly diverse functional pathways in the body, albeit a major part is related to the immune system (17). 
The collection of knowledge provided by all these efforts is anything but unuseful since they allow to define therapeutic pathways and targets that will bear fruit in the near future regarding clinical applications. However, population variability generally detracts from their clinical value as diagnostic or prognostic tools, although they may be used for populations at risk (18). A way of making the obtained knowledge in this field profitable would be to specifically define which of these markers are useful in each population. Aligned with this goal is the paper by Loeff et al. (14) on gene $M Y O 9 B$ polymorphisms. Furthermore, their study has the added value of having been performed on a scarcely studied population from the $\mathrm{CD}$ genetics standpoint, as is the population of South American regions with a major Amerindian component, whereas most studies to date are focused on Caucasian populations of European descent.

\title{
José Antonio Garrote-Adrados ${ }^{1}$ and Eduardo Arranz-Sanz ${ }^{2}$
}

\author{
${ }^{1}$ Laboratory of Genetics and Molecular Biology. Service of Medical Laboratory \\ Hospital Universitario “Río Hortega". Valladolid, Spain. \\ ${ }^{2}$ Instituto de Biología y Genética Molecular (IBGM). Universidad de Valladolid- \\ CSIC. Spain
}

\section{REFERENCES}

1. Zhong F, McCombs CC, Olson JM, Elston RC, Stevens FM, McCarthy CF, et al. An autosomal screen for genes that predispose to celiac disease in the western counties of Ireland. Nat Genet 1996;14:329-33.

2. Sollid LM. Hunting for celiac disease genes. Gastroenterology 2008;134:869-71.

3. Spurkland A, Sollid LM, Ronningen KS, Bosnes V, Ek J, Vartdal F, et al. Susceptibility to develop celiac disease is primarily associated with HLA-DQ alleles. Hum Immunol 1990;29:157-65.

4. Monsuur AJ, de Bakker PI, Alizadeh BZ, Zhernakova A, Bevova MR, Strengman E, et al. Myosin IXB variant increases the risk of celiac disease and points toward a primary intestinal barrier defect. Nat Genet 2005;37: 1341-4.

5. Van Belzen MJ, Meijer JW, Sandkuijl LA, Bardoel AF, Mulder CJ, Pearson PL, et al. A major non-HLA locus in celiac disease maps to chromosome 19. Gastroenterology 2003;125:1032-41.

6. Amundsen SS, Monsuur AJ, Wapenaar MC, Lie BA, Ek J, Gudjonsdottir AH, et al. Association analysis of MYO9B gene polymorphisms with celiac disease in a Swedish/Norwegian cohort. Hum Immunol 2006;67:341-5.

7. Cirillo G, Di Domenico MR, Corsi I, Gagliardo T, Del Giudice EM, Perrone L, et al. Do MYO9B genetic variants predispose to coeliac disease? An association study in a cohort of South Italian children. Dig Liver Dis 2007;39:228-31.

8. Giordano M, Marano C, Mellai M, Limongelli MG, Bolognesi E, Clerget-Darpoux F, et al. A family-based study does not confirm the association of MYO9B with celiac disease in the Italian population. Genes Immun 2006; 7:606-8.

9. Hunt KA, Monsuur AJ, McArdle WL, Kumar PJ, Travis SP, Walters JR, et al. Lack of association of MYO9B genetic variants with coeliac disease in a British cohort. Gut 2006;55:969-72.

10. Nuñez C, Marquez A, Varade J, Martinez A, Polanco I, Maluenda C, et al. No evidence of association of the MYO9B polymorphisms with celiac disease in the Spanish population. Tissue Antigens 2006;68:489-92.

11. Dubois PC, Trynka G, Franke L, Hunt KA, Romanos J, Curtotti A, et al. Multiple common variants for celiac disease influencing immune gene expression. Nat Genet 2010;42:295-302.

12. Plaza-Izurieta L, Castellanos-Rubio A, Irastorza I, Fernandez-Jimenez N, Gutierrez G, Bilbao JR. Revisiting genome wide association studies (GWAS) in coeliac disease: replication study in Spanish population and expression analysis of candidate genes. J Med Genet 2011;48:493-6.

13. Trynka G, Hunt KA, Bockett NA, Romanos J, Mistry V, Szperl A, et al. Dense genotyping identifies and localizes multiple common and rare variant association signals in celiac disease. Nat Genet 2011;43:1193-201.

14. Loeff T, Araya M, Perez-Bravo F. Frequency of MYO9B polymorphism in celiac patients and control subjects. Rev Esp Enferm Dig 2012;104:566-71.

15. Araya M, Mondragon A, Perez-Bravo F, Roessler JL, Alarcon T, Rios G, et al. Celiac disease in a Chilean population carrying Amerindian traits. J Pediatr Gastroenterol Nutr 2000;31:381-6.

16. Perez-Bravo F, Araya M, Mondragon A, Rios G, Alarcon T, Roessler JL, et al. Genetic differences in HLADQA $1 *$ and DQB1* allelic distributions between celiac and control children in Santiago, Chile. Hum Immunol 1999;60:262-7.

17. Trynka G, Wijmenga C, van Heel DA. A genetic perspective on coeliac disease. Trends Mol Med 2010;16:537-50.

18. Izzo V, Pinelli M, Tinto N, Esposito MV, Cola A, Sperandeo MP, et al. Improving the estimation of celiac disease sibling risk by non-HLA genes. PLoS One 2011;6:e26920. 